\title{
THE ENCHANTMENT OF LOCAL RELIGION Tangling Cultural Heritage, Tradition and Religion in Southern Europe
}

\author{
Cyril Isnart, Aix Marseille Univ., Centre National de la Recherche Scientifique - UMR \\ IDEMEC Aix-en-Provence
}

\begin{abstract}
This article addresses the combined dynamics between traditional religious manifestations and cultural heritage processes in order to better understand the reconfiguration of certain religious rituals, sometimes coined as local religion. After examining the entanglements of cultural heritage and religions in southern Europe, often silenced or minimized, I present recent case studies demonstrating that uses of religious traditions as cultural heritage are not uncommon and that the theoretical framework of secularization needs to be nuanced. At state or community level, religious practices seem to be enchanted, and at the same time enchant the region in which they take place. This analysis helps to understand the processes of contemporary social and cultural reconfiguration of the ways people think and what they make of their religious "traditions".
\end{abstract}

Keywords: southern Europe, cultural heritage, Catholicism, brotherhood, pilgrimage

\section{Local Religion in Perspective}

In the last decades of the twentieth century, under the term "local religion", historians and anthropologists developed a new framework for analysing Catholic practices and events in southern European contexts. This was a way to challenge the ecclesiastical, dogmatic, and erudite worldviews on spirituality, healing, or supernatural powers experienced by the people themselves, and also to take into account small-scale uses of saint and Virgin Mary cults in European zones. Local religion appeared to be a good concept to think with as it allows scholars to look at religion as a contextual experience, lived at the level of individuals and communities which are inscribed in peculiar territories and social networks, away from more generalizing theories and disincarnated statements on religiosity, holiness, or society. William Christian was the creator of the expression (1981), followed by Italian and French scholars analysing folk and popular religion (Lanternari 1982; Albert-Llorca 2002). They show that the field of local religion analysis - especially pilgrimages and the cults of the saints - paved the way for a more comprehensive reading of vernacular religious experiences, including parameters such as class conflicts, gender, imaginary, or ritual dynamics (Claverie \& Fedele 2014). In a certain way, the interest in local religion made it possible to return to ancient sources 
of knowledge, such as nineteenth-century European folklore inspired by philology. This literature conserves traces of thousands of ethnographic facts that were re-interpreted in a new perspective (Charuty 2001). Local religion analysis also permitted scholars to legitimate investigations into contemporary European religious sensibilities, such as the growing number of apparitions of the Virgin Mary or the renewal of pilgrimages (Claverie 2003; Eade \& Albera 2017), both phenomena often labelled insignificant when compared to the highly contested notion of the so-called secularization of European societies.

Later on, studies on manifestations of local religion accompanied the renewal of investigation into European regional identity movements that merged religion, identity-building processes and cultural heritage legitimation. For instance, the cult and pilgrimage of Saint Besse in the Italian Alps, studied in the early twentieth century by Robert Hertz (1913), came back in the anthropological discussion between Jeremy Boissevain $(1992,1999)$ and Jeremy MacClancy \& Robert Parkin (1997). This debate demonstrated that local religiosity is a rich and powerful object to be investigated in order to reveal how European societies deal with their religious past, how a local ritual can help to characterize the recent social and economic dynamics, and finally, to what extent representation of local identity can be built on a small-scale religious event such as the local pilgrimage of Saint Besse (Isnart 2009a). And just as ethnologists and anthropologists have noted a growing role for cultural heritage in the politics of tourism (Salazar 2010) as well as the conceptual and practical intersections of tourism and pilgrimage (Badone \& Roseman 2004), local religion has also been implicated in heritage-making processes during this same time. Tourism development and heritage policies have contributed to the endurance of certain forms of rituals, places of worship and supernatural entities within contemporary European societies and beyond (Boissevain \& Isnart 2017).

In this article, I address such combined dynamics between local religion and cultural heritage in order to better understand how local actors reconfigure some religious rituals and consider them as elements coming from the past and defining their current collective identities. Sometimes deemed as "traditions" and sometimes subject to political instrumentalization, always re-inscribed in the contemporary context and always used as a place and a time to perform one's identity, local religion as a cultural heritage property has to be examined in the light of its long-term history and its more recent uses in the context of heritage-making. I first draw from the entanglements of cultural heritage and religions in southern Europe, arguing that anthropological and ethnological literature is often unwilling to scrutinize this intimate relationship, or simply remains at the State-Church level. Then, I focus on small-scale case studies that provide new tools to understand, from below, the imbrication of heritage and religious experiences. In the last section, I give an analytical overview of my ethnographic investigation in the village of Tende in the French Alps. I describe the renewal of the local religion deemed as "local traditions" (Catholic brotherhoods and a local pilgrimage), as the entanglements of religious practices and cultural heritage reconfigurations.

\section{Religion and Cultural Heritage in Southern Europe}

For ethnologists working in Europe, the association of national identity with religion is commonplace. Many of the twentieth-century monographs have demonstrated that institutional rituals and narratives of the Church travelled from the sphere of the clergy to a more popular milieu, framing the daily life of people. In spite of the fall in institutional religious practice among the European population - the so-called secularization process (Gauchet [1985]1997; Taylor 2007) - religion has always worked as a national identity feature, which survived communism in the East (Tocheva 2017), democratization in the South (Giorgi \& Itçaina 2015-2016) and economic development in the North (Hervieu-Léger [1993]2000). This is clear when one looks at family structures, abortion legislation, violence within the Balkan region or in Ireland, resistance to religious diversity, creation of new pilgrimage sites, or structuration of religious radicalism. Even though some 
of the European governments and ecclesiastical institutions struggle against religious-oriented crises, armed conflicts, or underground resistance, the light, discrete, and obstinate little music of national religious identity is still playing. The political project of the European Union itself has been put under a Christian ascendance, showing that European democracies still define themselves, at least partly, on a religious basis. Diplomacy used the shared Christian past to justify southern nations' accession to the EU, while the difficulties Turkey finds on its way to entering the EU are not only linked to the recent authoritarian policies of president Erdogan. The winner of the Nobel Prize in Literature, José Saramago, preferred to leave Portugal after giving an alternative narrative of Jesus' life and stating that Catholicism had contributed to badly framing the European society as it is (Saramago 1991). The first European cultural element to be recognized at the EU level was the trail of the main medieval pilgrimage, Santiago de Compostela, which claims to be one of the major and most ancient links between European regions (Chemin 2016). The recent fire that partly destroyed Notre Dame of Paris Cathedral in April 2019 is a striking example of the intimate and sensitive connections between national feelings and religious heritage. ${ }^{1}$

Clearly, European cultural heritage does not escape religious influence. Anthropologists and folklorists have long acknowledged that the political building of the nation-state in European countries is an early social and political process, and touristification of religious sites is an important part of such dynamics. Association between religion and politics has had a great impact on what state administration and cultural brokers consider to be cultural heritage, that is to say, representing national identity, especially monuments, handicraft, festivals, architecture, or traditional music.

Many of the communities we as social scientists have been working with, while continuing their pious and devotional practices, try to include their religious goods and rituals in the realm of cultural heritage. Places of worship, pilgrimage sites, or religious buildings are simultaneously considered to be spiritual places, tourism assets as well as emblems of cultural differences and specificities (Di Giovine \& García Fuentes 2016; Bowman \& Sepp 2019). The case of the Sagrada Familia church in Barcelona (Catalonia, Spain) is surely one of the most powerful and well-known examples of this religiouspolitical association at national and ethnic level (Marine-Roig 2016: 103-105). The church was built as an expiatory chapel by a religious association of the late nineteenth century who wanted to celebrate and worship the spiritual entity of Jesus' family. If, at the beginning, devotees were paying for the construction, the monument quickly became an iconic emblem of Barcelona and the modernist architectural style of Antoni Gaudí, sustained by tourism. In the late 1950s, Gaudí's work was recognized as a specificity of Catalonian culture, and his buildings, including the Sagrada Familia, were inscribed on the Unesco World Heritage List in 2005. While the church is today an asset of local tourism policies, its religious functions still survive and provide a long-lasting example of religious heritage inserted in secular and heritage dynamics.

Moreover, such a heritage and tourism transfer also affected religious rituals. Following Nathalie Cerezales' work (2017: 211-248), in the 1930s, the authoritarian regime of Francisco Franco decided to add the Holy Week processions to the national heritage list in order to strengthen the Catholic feature of Spanish culture. In the nineteenth and early twentieth centuries, the religious landscape in Spain suffered radical transformations. Popular religious festivals, such as the famous processions of Holy Week, were disappearing and Liberals in Spain ordered the disintegration of religious art collections owned by the different monastic orders. Objects were transferred from churches, convents and seminars to public secular museums of regional art, were sold or were lost. In Valladolid for instance, the very large, heavy, and impressive sculptures in use within the brotherhoods for their Easter processions since the late sixteenth century were kept by the local museum. In the early twentieth century, the director wanted to assemble and rebuild them in their original configurations to showcase these 
valuable masterpieces of Spanish art. At the same time, he worked closely with brotherhoods and the Church to renew the ritual processions of Easter. After its conversion into the National Museum of Sculpture (1933), the view of the museum director was that this ritual renovation would help to publicize the museum's endeavours to work on the art pieces it conserved, and the brotherhoods and the Church seized the opportunity to come back to their devotional activity and to re-Christianize the local society. Later, and on a national scale, the authoritarian Franco regime used Holy Week processions to implement its ideology of national-Catholicism, and not surprisingly, added a series of such collective devotions to the list of Fiestas de Interés Turístico (festivals of touristic interest) just after the creation of this tourism management tool.

Having shed some light on regional cases, which show that policies of cultural heritage have much more to do with religion than we may think, I turn now to the religious quality of cultural heritage per se, which remains undeveloped in the literature and has only recently attracted interest among scholars. Academic interpretations of the role of religion in cultural heritage practices has tended to look at heritage-making as a secularization process, which is supposed to cancel out the religious power of the objects and to provide them with a lay and artistic aura. Few critical works take into account the religious dimensions of the heritage corpus and little has been written on the consequences of the use of religious goods as cultural heritage. Theoretical and methodological consequences of such a framework of understanding are manifold. ${ }^{2}$

Firstly, the association of religious heritage to nationalistic rhetoric leads to a naturalization of the religious side of cultural heritage. As a consequence, citizens, tourists, and locals generally associate history, the past, and religion to the current identity of places and groups they visit or form a part of. Italy, France, Spain, Portugal, as well as Greece and the Balkan countries, are all known for their cultural heritage which comes from the monotheist traditions: the postcard pictures of a white chapel on the
Mediterranean coast, of a church of Roman style in Provence, or of a Holy Week ritual in Andalucía, surely transmit a religious narrative of the respective national past because state heritage technologies combine sun, cuisine, wine, royal history, or festive events with religious items, as landmarks of the nation imaginary. Such phenomena are still to be explored today, both with the tools of history of culture and institutions in the past, and with the methodology of ethnography when considering the more recent and contemporary tourist and heritage uses of religion.

Secondly, because of the association between state and religious goods, religious cultural heritage is often thought about and analysed through the lens of administrative policies, state and intergovernmental legislations, or bureaucratic practices of different churches (Fornerod 2015). However, as disciplines of social sciences traditionally (but not exclusively) rooted in the common way of life of ordinary people, ethnology and anthropology can provide new insights on these profound, discrete, and powerful facts. These approaches generally look at popular culture, and everyday practices and routines, such as education, leisure, aesthetics or technologies, in order to provide alternative views on religious macrodynamics. Some recent anthropological works show that, like Carnival (Tauschek 2009) or monuments (Fabre 2000), religious ceremonies, ritual objects, and cosmologic beliefs are also used as people's heritage resources (Andézian \& Décobert 2018; Trevisan Semi, Miccoli \& Parfitt 2013; Cohen-Aharoni 2017; Isnart 2012a; Di Giovine 2015). Besides that, notions such as participation, citizenship, and cultural rights have begun to enter the field of administrative policy of culture (especially with the Faro Convention [The European Council 2005] and the Unesco Intangible Cultural Heritage Convention [Unesco 2003]). Scholars working on heritage-making have shown that today not only are educated specialists working to safeguard cultural goods, but also the very people who usually lead heritage projects regularly claim for recognition of their monuments or festivals, or fight against cultural endangerment. Local 
religion, as ritual practices linked to a territory and a community, entered these dynamics and this fact calls for a more accurate exploration of the role of religion in the small-scale context of heritage-making.

\section{The Past, Heritage and Religion at the Local Level}

Exploring heritage activities related to religious objects and places leads us to reveal implicit and non-written norms and values, non-administrative contexts of performance, and networks of actors away from economic and cultural centres, which I analysed elsewhere as self-heritagization (Isnart 2015) or what Harrison coined as unofficial heritage-making (2010). It also reveals cooperation, opposition, and negotiation between ordinary heritage activities and the heritage regime governing state conservation and mediation practices (Isnart 2012b; Adell et al. 2015). As a local micro-analytic framework, self-heritagization analysis opens up a way to observe and analyse how the actors and the institutions of local religion enter the field of cultural heritage. It enables assessment of what technologies heritage-makers implement or create to become their own heritage managers. Such practices of heritage remain in the hands of a network of individuals, firmly attached to a territory, who develop a narrative of their history, claim to be valuable experts of their religious legacy, produce cultural mediation publications, and act as facilitators between administrations of heritage and local groups. If both states and local groups encourage religious goods and practices to be labelled as cultural heritage, that is distinguished from the rest of the world that people inhabit, cultural anthropology and ethnology are perhaps the best prepared disciplines to explore what the connections are between the public heritage spheres and local religion actors, and what their specificities may be.

This is true, firstly, because our disciplines can assume a long-lasting theoretical exploration of uses of tradition, the past, and identity in many contexts; and secondly, because directing the focus towards individuals and local groups allows us to see how people perform their own conceptions of heritage management, how they deal with the national administrative frame, and what social status they give to religion.

Ellen Badone has recently argued that Brittany is a good place to understand the coming of religion to the cultural and heritage floor (2015). She called this fact a "re-enchantment" of a secularized world in the Weberian sense. Religious monuments there are now considered as lieux de mémoire (Nora [1984]1989) and art objects, mediating a certain sense of spirituality and transcendence. Catholicism once structured the collective and individual life of this rural population; it then declined after World War II. Today the situation is paradoxical: people do not attend mass on a regular basis but churches are valued as regional identity symbols. ${ }^{3}$ Cultural heritage is today the main tool people use to give a meaning to churches or religious sculptures and paintings. Nonprofit associations hire young people to act as guides for religious tours, search for restoration funding, and write syllabi for the religious understanding of artworks. Even though the Catholic Church itself participates in the process, but with few means and little staff, these popular dynamics are quite visible. The use of sacred places themselves is partly disconnected from regular clergy supervision. What is important now is the connection people are building with the past of the region, with a humanistic understanding of the spiritual human condition, with a celebration of the quality of religious art. In sum, the Catholic lay associations from Brittany try to transmit an experience of the religious past during the guided tours of churches and monuments. This is the path local heritage actors find and follow in order to keep their buildings standing, but this is also a strategy to preserve the religious feelings and history of Brittany.

On the other side of Europe, on the island of Rhodes, the Catholics also safeguard their religious heritage (Isnart 2014, 2015) as the Bretons do. Catholics form a minority of less than 1,000 people, either born during the Italian colonial period in the island's history or recently arrived for their retirement. They live today in a mainly Greek Orthodox 
context, but are passionate about their past, their architecture, and their rituals. There is not exactly a feeling of "disenchantment", nor a strong process of secularization; however, the low number of devotees, the weak workforce available, and the fragile structure of the community, all make it difficult to speak about living a rich religious life. All the activities and procedures are led by two or three people intimately linked to parish life, who act as the official representative of the national Catholic administration. The person in charge of the archives, for instance, collects ancient newspapers, birth, marriage, and death records of the parishes, postcards of the churches, architectural archives, and songs and prayers used during the rituals. Through the publication of a book in Italian, entitled Le Chiese che Furono... (Churches that used to be...), she compiled in a sole printed lieu de mémoire, all the places, rituals, names of people, stories, and dates of the several places of worship the Roman Catholics have known and frequented since the beginning of the twentieth century. The intention of the author is to preserve a set of religious memories, acknowledging that many of the churches are now converted into Greek Orthodox churches and that people who have lived in these places are disappearing little by little. Another of her motivations lies in her faith and in the way in which she considers the practice of maintaining archives, writing about the local history, and safeguarding memories as a testimony of her loyalty to the memory of the local Catholic ancestors and, moreover, a devotion to God, the Virgin Mary, and to the saints.

From the two cases one can easily conclude that religion and care of culture are intimately connected, and moreover, that religious beliefs are not separated from heritage practices of conservation. Somehow, cultural heritage of small communities such as Catholics in Greece or in Brittany clearly and efficiently functions as a religion and identity preserver, as it does at the scale of the nation-state. But what happens when one explores local religion manifestations in which devotees and heritage keepers seem to be far away from the clergy and its administration, or in which there is no or little bureaucratization of the ritual routines?

\section{How to Reconfigure Local Religion? A View from Tende}

On the border between France and Italy, in a mountain region dividing Piedmont, Liguria and Provence, some villages of a few hundred inhabitants live in such a context. They have transformed their religious traditions like pilgrimage and brotherhood processions into reliable cultural heritage. This process allows them to claim for the recognition of their local past, to recall memories untold in the official discourse, to produce alternative narratives of their identity, and to perform their religious feelings. This rural and mountain region is marked by a strong Catholic background in its architecture, urbanism, and daily and festive life. Church masses, clergy benedictions, saints and God are part of all rites of passage, collective festivals, and territory celebrations, and they are all said to be part of the ancestors' legacy, which gives cultural and identity consistency to the current community. In the village of Tende in particular, apart from the celebrations listed in the universal Catholic calendar, one can witness the Feast of Our Lady of Mercy (25 March), the Easter procession, the Feast of Saint John the Baptist (24 June), the Feast of Saint Eloi (2nd week of July) and of Saint Roch (16 August), the various festivals of the hamlets (summer) and the Feast of Age Classes (October). The case of Tende has been presented in several papers already (Isnart 2009b, 2012b, 2013), and I intend here to underline the main features of the transformations that the village's religious traditions have undergone since the beginning of the twenty-first century. They enter a new regime of performance and morality - that of the recollection of a religious past and a re-enchantment of local traditions. Two examples of religious performances in Tende, brotherhood processions and pilgrimage, clearly exemplify the heritage dynamics. They show that the renewal of traditional contents comes hand in hand with a twofold rhetoric of reconfiguration: past-presencing, defined by Sharon Macdonald as the modalities "by which the past may inhabit the present" (2013: 16) and the technology of enchantment, extending the view of Alfred Gell on art to traditions and rituals, as the strategies implemented to 
make something fascinating and magical (1992). It is important to recall that there are obviously other performances and other reconfiguration patterns at work in the village, and that the following descriptions are given to illustrate the usefulness of these concepts to better capture what is at stake when some members of a community want to transform their religious experiences into cultural heritage.

\section{Religious Brotherhoods and the Collective Past}

Many of the Tende families participate in one of the two devotional brotherhoods of penitents, called confrérie de pénitents in French or confraternita in Italian. These pious associations assemble male and female Catholic lay people to publicly demonstrate their faith through street rituals, solidarity in health or money troubles, and devotional penitence. It is commonplace, among the erudite members, to hear that their associations hark back to medieval times, when groups of devotees chose to publicly suffer for the various illnesses the society endured at that time. Later, these groups turned into charity movements, sometimes continuing to display their faith through street processions. Such brotherhoods have survived - with more or less continuity - and they still perform in various places in southern Europe (Portugal, Spain, France, Italy). They have different roles, visibility, and importance in the locals' collective life. The two brotherhoods of Tende - divided into the black or the white penitents associations according to the colour of their ritual costume - own their own chapels, devotional instruments, specific liturgy and songs. They are linked, via national and international federal structures, with the other brotherhoods in the region, in Italy and France. Members of the brotherhoods wear ritual costumes, made of a white or black robe, plus a veil for women. Holy Week is the main event in their calendar. On Holy Wednesday, the brotherhood of the black penitents builds an ephemeral altar in their chapel. This altar is made of a huge cross, arma christi (symbols of the passion of Jesus Christ), flowers, candles, and a full-size wood sculpture of a dead Christ. On Holy Friday, the two confréries perform a lengthy procession with the
Christ sculpture, going from their chapels to the central church, where the priest celebrates the death of Christ.

As owners of a material and intangible legacy, the brotherhoods develop safeguarding actions to maintain and restore their buildings and objects, offer guided tours to tourists visiting the village, and archive their musical and ritual repertoires through video recording. They do so with the help of the regional administration of cultural heritage or by their own means with volunteers of the village. The heritage claim of the brotherhoods dates from the end of the 1980s, when a significant number of couples of natives came back to live in the village, for their retirement, after a long period of work in the coastal region of Côte d'Azur. During the previous four decades, they only used to spend their holidays in Tende and thus maintained the link between them and their kin villagers who were still living there. The renewal of the brotherhoods corresponds to what Jeremy Boissevain called "revitalization" (Boissevain 1992), while the mainly religious features of the brotherhoods give another flavour to the heritagization process in Tende and provide a solid ground for the recollection of the past.

The members worked away from the village for decades and because they adapted their daily routine to a more urban one, they now perform the common procession of Holy Week on the Holy Friday night, instead of the Holy Thursday. Before World War II, the procession was also longer and different. Each brotherhood used to have its own procession. First in line was a member dressed in blue or in red, carrying a large cross. Following a specific path from their chapels to a meeting point in the centre of the village, they joined to reach the parish church together. As is the case of many European rural areas, this change makes it possible for people living in the urban cities to reach the village at the beginning of the weekend, just in time to participate in the emblematic ritual of the brotherhood. Even though they do not attend on a regular basis the parish activities of the village or their cities, and even though they are conscious that the procession is not the same as it used to be in the past, members of the 
brotherhoods always secure their presence during the procession, as a duty they have to pay to their ancestors who built the chapels, founded the brotherhood, and transmitted the ritual.

The members of the confréries always argue that the revitalization of the procession is a performance of their ancestors' past, because it recalls the way in which the former inhabitants of the village - all considered ancestors of the current brotherhoods' members - used to live. The interviews I conducted among the members and the conversations about the past I have participated in during the rituals and the collective activities of the brotherhoods make clear that the village's past remains a strong reference for the penitents today. They like to recall the transformations their community and way of life have suffered since the early twentieth century. When agriculture and transhumance were the only means to survive and feed the families, and when famine, death, and diseases endangered the lives of children and elderly people, members of the brotherhood could benefit from the solidarity of the other members. This solidarity is considered as a genuine feature of the religious framework of the village in the past. Yet, it is not only the artistic, aesthetic, or architectural past - or simply the memories of the ancient processions - that the brotherhoods want to protect through their heritage activities. They also operate the remembrance of how religious life used to be in the village in the past.

To be part of the procession and of the brotherhood is a way to participate in the remembrance of the ancestors' past. The fact that the entire materiality of the devotional practices (ritual costumes, devotional objects, places of worship) still survives certainly helps to maintain past-presencing discourses. Nevertheless, material testimonies would not be enough without members' will to ensure the re-enactment of the past as a narrative and a ritual performance. A similar strategy is applied to safeguard another ritual of the village, a small-scale pilgrimage at the margins of the territory, though it is subject to a stronger enchantment process than the brotherhoods themselves.

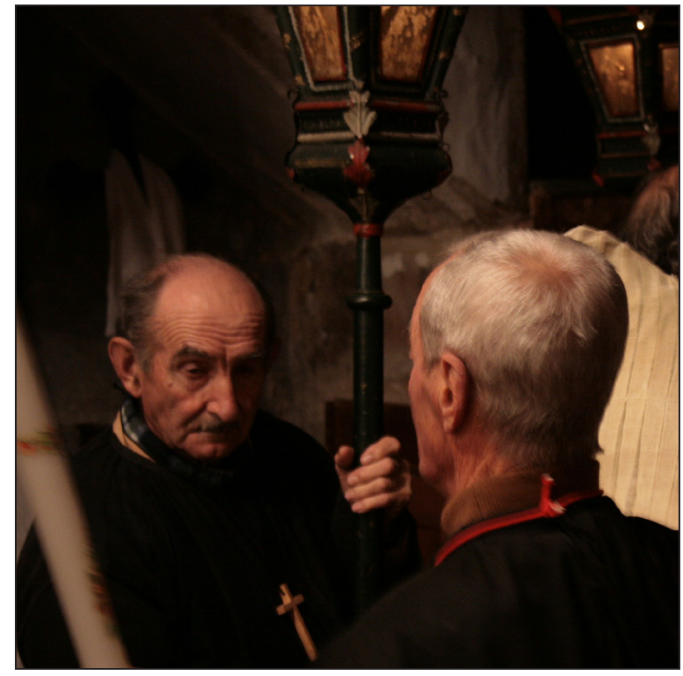

Figure 1: Two black penitents waiting for the departure of the Good Friday procession, Chapel of the Mercy, Tende. (Photo: Cyril Isnart, 2007)

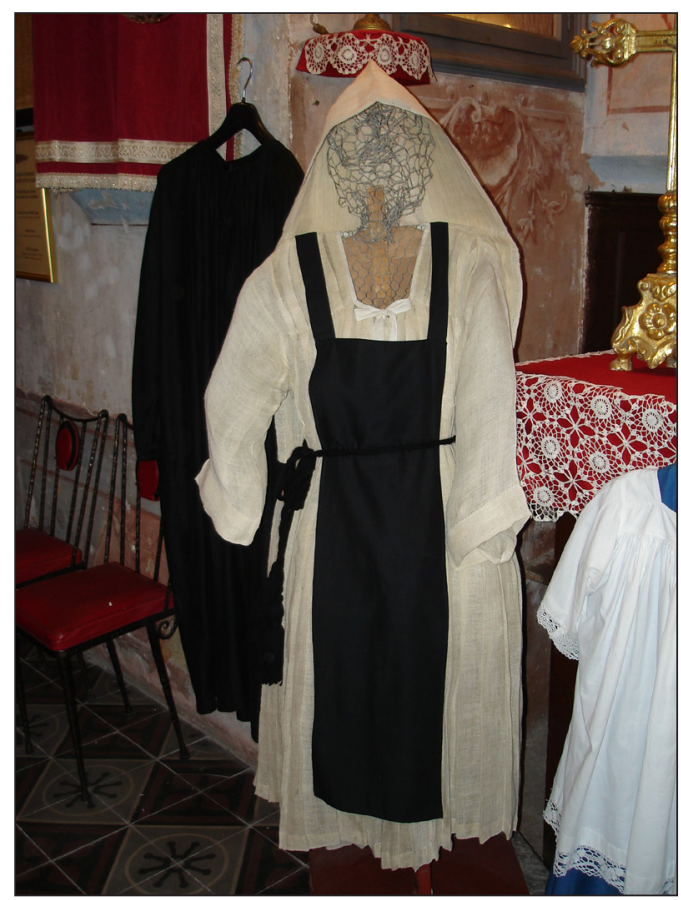

Figure 2: Display of black penitents female and male costumes, Chapel of the Mercy, Tende. (Photo: Cyril Isnart, 2007) 


\section{Enchanting a Local Pilgrimage}

The small hamlet of Vievola is accessible by a ten-minutes car ride from Tende on the road leading to Italy. It is an ancient agricultural settlement of the poorest local families, coming from Italy, made of a dozen former farms, a chapel, and some rural houses next to a mountain river. Today, a golf course occupies the whole area and some newcomer families have bought the buildings for their holidays. A pilgrimage first occurred to thank the Virgin Mary for her protection during a plague that affected Tende at the end of the seventeenth century. Even though the population and economic function of Vievola have changed dramatically during the last decades, passing from a local rural economy to a leisure space, the chapel and the local pilgrimage still survive and remain as important as they were in the past.

After a series of afternoon ceremonies the week before the pilgrimage, the pilgrimage day itself consists of a procession in the former fields around the hamlet, a mass in the chapel, speeches by local politicians, collective meals around the chapel, and traditional dances and singing parties. Today, the pilgrimage gathers two hundred participants, made up of past inhabitants of the hamlet, friends of these families, villagers of Tende, and musicians and dancers from the Italian border region. When you visit the place in winter, looking at all the closed shutters of the houses and searching for inhabitants to talk to, it could be difficult to imagine the activity and animation of this little territory of Tende the day of the pilgrimage: a lot of cars crammed along the road, many groups waiting for the picnic time, old and young people attending the mass outside the chapel, the long snake of the procession through the hamlet, collective singing and traditional dances accompanied by the two musicians next to the chapel, and the presence of the mayor (elected head of the municipal territory) and senator (representative of the regional zone at the French Senate). This vitality is certainly one of the reasons why the pilgrimage and the festive activities are always labelled as the more authentic and genuine celebrations that tourists, media, or ethnologists have to experience if they want to get to know real local life. Combining collective religious rituals, instrumental music, traditional dance performances, masculine vocal singing, and sharing meals and drinks, the pilgrimage of Vievola functions, for the locals, as an important representation of the cultural identity the people of Tende like to transmit to visitors.

Locals share the belief that they are participating in a celebration and a performance of their own festive culture, but some of the people I talked with still argue for a more complex understanding. In order to prevent me from taking for granted these simple and politically correct discourses and performances of a so-called Tendasque identity, I have been told other stories about the hamlet and its inhabitants. Firstly, among the population of Tende, Vievola people are not considered fully-fledged Tendasque, as their Italian origin is commonly silenced. I only discovered their history as descendants of Italian migrants after months and months of fieldwork. Secondly, the singing and dance traditions that take place in Vievola and Tende, as samples of local culture, were not always the most shared and beloved cultural practices of Tende's inhabitants; in the 1950s, dances like the waltz and the tango were preferred to the Piedmontese-style dance and singing. Thirdly, at first, families of Vievola were not welcome at village celebrations and were stigmatized as a rural and backward population; they had to wait until the 1980s to be accepted as valid partners for alliances with Tende's families. The series of social and cultural differences with which the people of Vievola were defined contributed to structuring and dividing the village community into various subgroups, yet the heritage narrative and performances about and in Vievola show a more integrated, coherent and unbroken image of the village as a whole (Isnart 2012b).

It is not the place here to assess the moral stakes of such strategies of distinction, which are a common modality for ethnic groups to deal with identity and difference (Barth 1969). I would argue that it opens a path to better understand how the rhetoric of enchantment is implemented in this particular society. Somehow, the camouflage of the difference between 
Vievola's and Tende's people reveals the techniques of enchantment that are put into action in the case of the Vievola festival.

The family in charge of the organization of the pilgrimage, with the help of the municipal council and the many inhabitants who gather in the hamlet during the festival, performs and talks about their festival as a peculiar, genuine, and emotional meeting. Nostalgia for the former celebrations, memories of the ancestors, traditional singing and dancing, and the sharing of local meals and alcohol, all help to make the pilgrimage and the hamlet a nostalgic moment and an enchanted place. In the mouth of the mayor and the senator, the pilgrimage constitutes a unique occasion for local people to meet and remember how the village community used to be and towards which kind of social ties and solidarity the present popu- lation has to look. The families taking part in this local religious festival are all touched by the friendly ambiance, the easy transmission and performances of dances and songs. They all insist on the singularity of the Vievola feast, as the closest re-enactment of what their ancestors would have experienced in the past. In the same way that the brotherhoods mobilize narratives of the rural and Catholic past of the village, the mayor and the family who organizes the pilgrimage try to recall some elements of the history that transmit a holy and enchanted understanding of their festival. These are: the massive plague that took place in the seventeenth century, leading to the death of hundreds of inhabitants; the pious multitude of the congregations in the mid-twentieth century; and the spiritual importance of the fight for the survival of the festival. The performance of traditional danc-

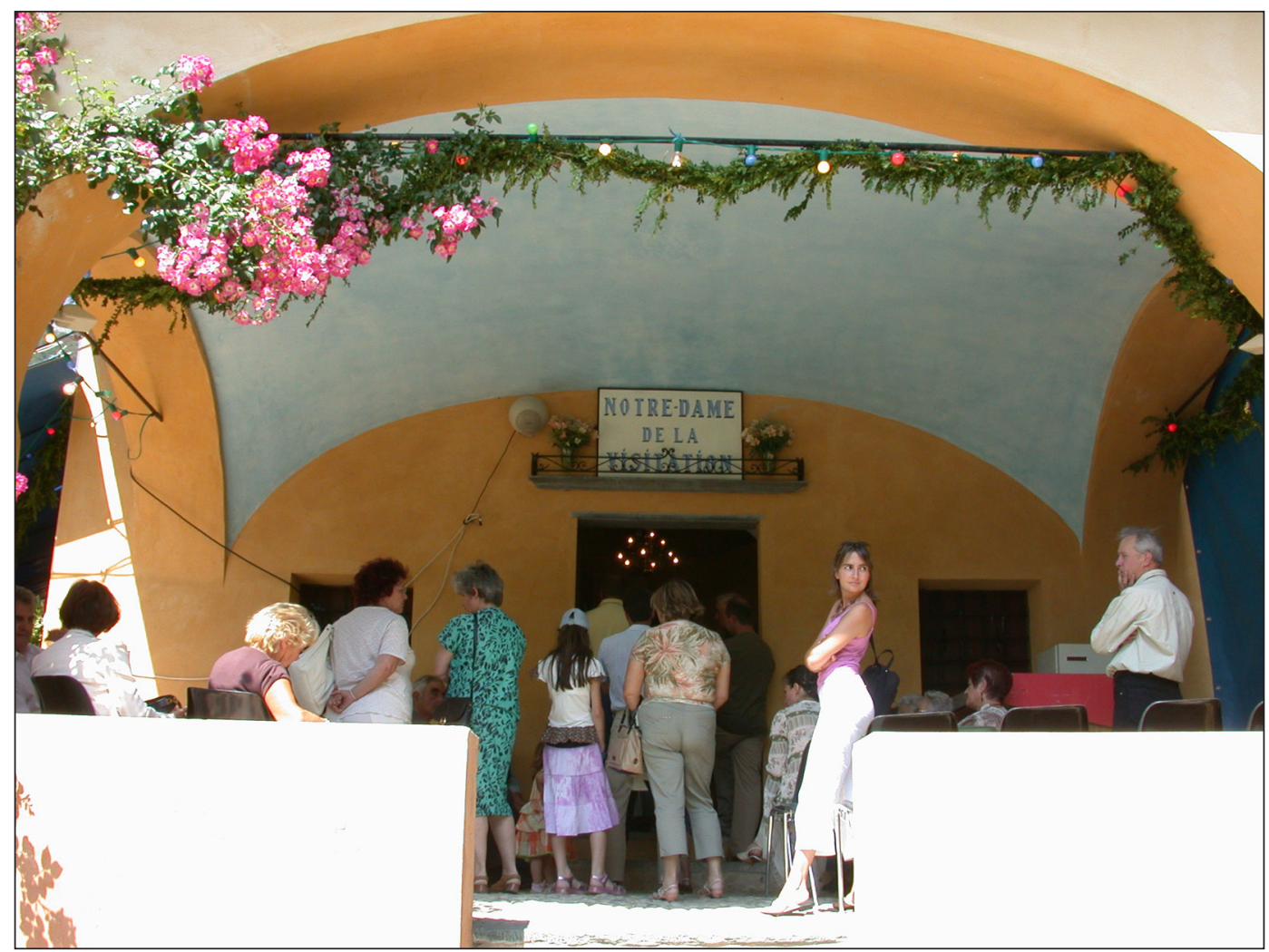

Figure 3: Main entrance of the Chapel of Vievola (Our Lady of the Visitation), during the religious service. (Photo: Cyril Isnart, 2008) 


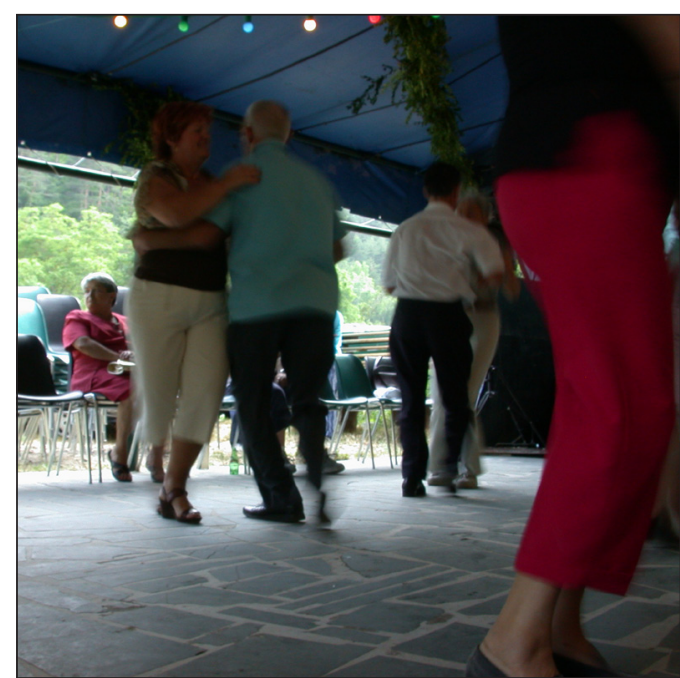

Figure 4: People dancing in the afternoon of the Vievola pilgrimage. (Photo: Cyril Isnart, 2008)

es and songs by elderly and young locals, with the help of musicians coming from the Italian side of the border, the coming of families from the village and abroad especially for the festival, the sharing of local food and drinks, the procession that crosses the Vievola fields and buildings, and the friendly presence of the local politicians, are some of the features people like to highlight in order to give a significant, spiritual, and emotional value to the pilgrimage.

\section{Conclusion}

As the examples from Brittany, Greece and southern France have shown, religious traditions - be they devotional practices, built heritage, or narratives of the past - which are subject to heritagization help us to delve into the very processes of contemporary social and cultural reconfiguration of what local people think represent their tradition. Local religion, expressing the appeal to the past, the memories of the community, the sacred art and material artefacts, all seem to constitute an important device with which to rearticulate religious feelings, beliefs, territory history, and group identity. People turn religion into cultural heritage without losing or denying their spiritual or divine aspirations. Heritage-making in local religious contexts is not a total destruction of religion itself, because religion and heritage go hand in hand at the local and national levels and the narratives offered by tourism, museums, or history confirm this association. Furthermore, social groups engage in the procedures of cultural heritage to protect their goods, rituals, and faith, by integrating the general and common associations of cultural heritage representations with religious content. In these situations, the theoretical framework of a massive and unquestionable secularization of European societies is not defendable, or at least needs to be nuanced. Investigating religious heritage-making helps us to understand the multifaceted reconfigurations that the religious sphere suffers, instead of shrugging our shoulders at the disappearance of religious feelings in collective life.

On the contrary, either at state level or at the micro-level of small villages, religious practices seem to be enchanted, and at the same time enchant the region in which they take place. Obviously, on the one hand, the visibility of other religions, from Paganism (Fedele 2013) to Islam (Mapril \& Blanes 2013), is more and more important and paints new religious landscapes in many regions of Europe. It is right, on the other hand, that difficult migrations across the continent, economic structural crises, and violence labelled as fundamentalist put an end to a naïve view of European destiny (Kattago 2017). But it is not without interest that European ethnologists and anthropologists look at what people do through the reconfigurations of their religious traditions: observing how people write their own version of the past, adapt their rituals to a new age, and recall the memories of their ancestors, through a sometimes explicit heritage claim of their religious feelings, performances, and beliefs, can sustain anthropological comparisons with other kinds of religiosity and systems of beliefs. These European religious and heritage activities could probably take place in any context, yet with more or less difficulty. Nevertheless, the reconfiguration of religious traditions in Europe may also be one of the contexts anthropologists can explore to participate in the more general and global scientific project of the anthropology of contemporary religions. 


\section{Notes}

1 Since May 2019, a five-years research project, funded by CNRS (National Center for Scientific Research) and the Ministry of Culture aims at helping the reconstruction team to study the Cathedral recovery. A social sciences group is also established to study the emotions, social mobilizations and effects the fire has on the various communities working and living around Notre-Dame. See: Notre-Dame, la recherche s'organise, Le journal du CNRS, May 5, 2019, Léa Galanopoulo, https://lejournal.cnrs.fr/articles/notredame-la-recherche-sorganise.

2 Elsewhere, we proposed to scrutinize this particular, changing, sometimes conflicting but always close relation and to call it the "Religious Heritage Complex" (Isnart \& Cerezales 2020).

3 See Löfgren 2020, in this issue, for the same configuration in Sweden.

\section{References}

Adell, Nicolas, Regina Bendix, Chiara Bortolotto \& Markus Tauschek (eds.) 2015: Between Imagined Communities of Practice: Participation, Territory and the Making of Heritage. Göttingen: Göttingen University Press. DOI: https://doi.org/10.4000/books.gup.191.

Albert-Llorca, Marlène 2002: Les Vierges miraculeuses: Légendes et rituels. Paris: Gallimard.

Andézian, Sossie \& Christian Décobert (eds.) 2018: La Terre sainte en héritage. Paris: Cerf.

Badone, Ellen 2015: Religious Heritage and the Reenchantment of the World in Brittany. Material Religion 11: 4-24. DOI: https://doi.org/10.2752/20539321 5X14259900061517.

Badone, Ellen \& Sharon R. Roseman (eds.) 2004: Intersecting Journeys: The Anthropology of Pilgrimage and Tourism. Urbana: University of Illinois Press.

Barth, Frederik 1969: Ethnic Groups and Boundaries: The Social Organization of Culture Difference. Oslo: Universitetsforlaget.

Boissevain, Jeremy (ed.) 1992: Revitalizing European Rituals. London: Routledge.

Boissevain, Jeremy 1999: Continuity and Revitalization in European Ritual: The Case of San Bessu. Journal of the Royal Anthropological Institute 5(3): 461-462.

Boissevain, Katia \& Cyril Isnart 2017: Tourisme, patrimoine et religions en Méditerranée: Usages culturels du areligieux dans le catholicisme et l'islam contemporains (Europe du Sud-Maghreb). Mélanges de l'École française de Rome, Italie et Méditerranée modernes et contemporaines. DOI: https://doi.org/10.4000/mefrim.3423.

Bowman, Marion \& Tiina Sepp 2019: Caminoisation and Cathedrals: Replication, the Heritagisation of Religion, and the Spiritualisation of Heritage. Religion 49(1): 74-98. DOI: https://doi.org/10.1080/0048721X.2018.1515325.
Cerezales, Nathalie 2017: Exposer le patrimoine d'origine religieuse en Espagne: De la muséologie à la museographie. Ph.D. Paris: History of Cultural Heritage, Paris I Panthéon Sorbonne.

Charuty, Giordana 2001: Du catholicisme méridional à l'anthropologie des sociétés chrétiennes. In: Dionigi Albera, Anton Blok \& Christian Bromberger (eds.), L'anthropologie de la Méditerranée. Paris: Maisonneuve Larose, 359-385.

Chemin, Eduardo 2016: Re-inventing Europe: The case of the Camino de Santiago de Compostela as European Heritage and the Political and Economic Discourses of Cultural Unity. International Journal of Tourism Anthropology 5(1-2). DOI: https://doi.org/10.1504/IJTA.2016.076851.

Christian, William 1981: Local Religion in Sixteenth-Century Spain. Princeton: Princeton University Press.

Claverie, Elisabeth 2003: Les Guerres de la Vierge: Anthropologie des apparitions. Paris: Gallimard.

Claverie, Elisabeth \& Anna Fedele (eds.) 2014: Incertitudes et religions vernaculaires/Uncertainty in Vernacular Religions. Social Compass 61(4): 487-496. DOI: https://doi. org/10.1177/0037768614546996.

Cohen-Aharoni, Yemima 2017: Guiding the "Real" Temple: The Construction of Authenticity in Heritage Sites in a State of Absence and Distance. Annals of Tourism Research 63: 73-82. DOI: https://doi.org/10.1016/j.annals.2016.12.010.

Di Giovine, Michael 2015: When Popular Religion Becomes Elite Heritage: Tensions and Transformations at the Shrine of St. Padre Pio of Pietrelcina. In: Mike Robinson \& Helaine Silverman (eds.), Encounters with Popular Pasts: Cultural Heritage and Popular Culture. Cham: Springer International, 31-47. DOI: https://doi.org/10.1007/9783-319-13183-2_2.

Di Giovine, Michael \& Josep-Maria García Fuentes (eds.) 2016: International Journal of Tourism Anthropology. Special Issue on Sites of Religion, Sites of Heritage: Exploring the Interface between Religion and Heritage in Tourist Destinations 5(1-2).

Eade, John \& Dionigi Albera (eds.) 2017: New Pathways in Pilgrimage Studies. New York \& Abingdon: Routldege.

Fabre, Daniel (ed.) 2000: Domestiquer l'histoire: Ethnologie des monuments historiques. Paris: Maison des Sciences de l'Homme. DOI: https://doi.org/10.4000/books.editionsmsh.2861.

Fedele, Anna 2013: Looking for Mary Magdalene: Alternative Pilgrimage and Ritual Creativity at Catholic Shrines in France. Oxford: Oxford University Press. DOI: https://doi. org/10.1093/acprof:oso/9780199898404.001.0001.

Fornerod, Anne (ed.) 2015: Funding Religious Heritage. Farnham: Ashgate. DOI: https://doi.org/10.4324/9781315583679.

Gauchet, Marcel (1985)1997: Disenchantment of the World: A Political History of Religion. Princeton: Princeton University Press.

Gell, Alfred 1992: The Technology of Enchantment and the Enchantment of Technology. In: Jeremy Coote \& Anthony Shelton (eds.), Anthropology, Art, and Esthetic. Oxford: Oxford University Press, 40-63. 
Giorgi, Alberta \& Xabier Itçaina (eds.) 2015-2016: Religion and Local Politics in Southern Europe, 3 section issues of Religion, State and Society 43(2), 2015, 44(1), 2016, 44(3), 2016.

Harrison, Rodney 2010: Heritage as Social Action. In: Sussie West (ed.), Understanding Heritage in Practice. Manchester \& Milton Keynes: Manchester University Press in association with the Open University, 240-276.

Hertz, Robert 1913: Saint Besse: Étude d'un culte alpestre. Revue de l'histoire des religions 67: 115-180.

Hervieu-Léger, Danièle (1993)2000: Religion as a Chain of Memory. New Brunswick: Rutgers University Press.

Isnart, Cyril 2009a: Recent papers about Robert Hertz and St. Besse. Etnográfica 13(1). DOI: https://doi.org/10.4000/ etnografica.1277.

Isnart, Cyril 2009b: Pratiques rituelles de la Semaine Sainte et dynamiques contemporaines: Le reposoir del'archiconfrérie des pénitents noirs de Tende (Alpes-Maritimes). In: Marlène Albert-Llorca, Christine Aribaud \& Jean-Bernard Mathon (eds.), Décors de la semaine sainte en Méditerranée: Arts, rituels et liturgies. Toulouse: Framespa, 323-334.

Isnart, Cyril 2012a: The Mayor, the Chapel and the Ancestors: Clientelism, Emotion and Heritagisation in Southern France. International Journal of Heritage Studies 18(5): 479494. DOI: https://doi.org/10.1080/13527258.2011.632640.

Isnart, Cyril 2012b: Les patrimonialisations ordinaires: Essai d'images ethnographiées. ethnographiques.org 24, http:// www.ethnographiques.org/2012/Isnart.

Isnart, Cyril 2013: Espace du passé: Évocations nostalgiques et hétérotopie mémorielle à Viévola. Ethnologie française 43(1): 75-82. DOI: https://doi.org/10.3917/ethn.131.0077.

Isnart, Cyril 2014: Changing the Face of Catholicism in a Tourist Context: Ritual Dynamic, Heritage Care and the Rhetoric of Tourism Transformation in a Religious Minority. Journal of Tourism and Cultural Change 12(2): 133-149. DOI: https://doi.org/10.1080/14766825.2014.915088.

Isnart, Cyril 2015: Self Heritage-making and Religious Minority in Greece: An Ethnography of Heritage Activities outside of the Cultural Institutions. In: Nicolas Adell, Regina Bendix, Chiara Bortolotto \& Markus Tauschek (eds.), Between Imagined Communities of Practice: Participation, Territory and the Making of Heritage. Göttingen: Göttingen University Press, 171-184. DOI: https://doi.org/10.4000/books.gup.223.

Isnart, Cyril \& Nathalie Cerezales (eds.) 2020: The Religious Heritage Complex: Legacy, Conservation and Christianity. London \& Oxford: Bloomsbury. DOI: https://doi. org/10.5040/9781350072541.ch-014.

Kattago, Siobhan 2017: The End of the European Honeymoon? Refugees, Resentment and the Clash of Solidarities. Anthropological Journal of European Cultures 26(1): 35-52. DOI: https://doi.org/10.3167/ajec.2017. 260103.

Lanternari, Vittorio 1982: La religion populaire: Prospective historique et anthropologiques. Archives des Sciences Sociales des Religions 53(1): 121-143. DOI: https://doi. org/10.3406/assr.1982.2245.
Löfgren, Eva 2020: Reconstruction as Enchantment Strategy: Swedish Churches Burnt, Rebuilt and Rethought. Ethnologia Europaea 50(1): 52-72. DOI: https://doi. org/10.16995/ee.1895.

MacClancy, Jeremy \& Robert Parkin 1997: Revitalization or Continuity in European Ritual? The Case of San Bessu. Journal of the Royal Anthropological Institute 5(3): 61-78. DOI: https://doi.org/10.2307/3034365.

Macdonald, Sharon 2013: Memorylands: Heritage and Identity in Europe Today. London \& New York: Routledge. DOI: https://doi.org/10.4324/9780203553336.

Mapril, José \& Ruy Blanes (eds.) 2013: The Best of all Gods: The Sites and Politics of Religious Diversity in Southern Europe. Leiden: Brill Publishers. DOI: https://doi. org/10.1163/9789004255241_002.

Marine-Roig, Estela 2016: The Impact of the Consecration of "La Sagrada Familia" Basilica in Barcelona by Pope Benedict XVI. International Journal of Tourism Anthropology 5(1/2): 95-115. DOI: https://doi.org/10.5377/arquitectura.v1i2.9200.

Nora, Pierre (1984)1989: Between Memory and History: Les Lieux de Mémoire. Representations 132. DOI: https://doi. org/10.2307/2928520.

Salazar, Noel B. 2010: The Globalisation of Heritage through Tourism: Balancing Standardisation and Differentiation. In: Sofia Labadi \& Colin Long (eds.), Heritage and Globalisation. London: Routledge, 130-146. DOI: https:// doi.org/10.4324/9780203850855.

Saramago, José 1991: O Evangelho segundo Jesus Cristo. Lisbon: Caminho.

Tauschek, Markus 2009: Cultural Property as Strategy: The Carnival of Binche and the Creation of Cultural Heritage and Cultural Property. Ethnologia Europaea 39(2): 67-80.

Taylor, Charles 2007: A Secular Age. Cambridge: Belknap Press of Harvard University Press.

The European Council 2005: Convention on the Value of Cultural Heritage for Society.

Tocheva, Detelina 2017: Intimate Divisions: Street-Level Orthodoxy in Post-Soviet Russia. Berlin: LIT.

Trevisan Semi, Emanuela, Dario Miccoli \& Tudor Parfitt (eds.) 2013: Memory and Ethnicity: Ethnic Museums in Israel and the Diaspora. Newcastle-upon-Tyne: Cambridge Scholars Publishing.

Unesco 2003: Convention for the Safeguarding of the Intangible Cultural Heritage.

Cyril Isnart is an anthropologist, senior researcher at the Institut d'ethnologie méditerranéenne, européenne et comparative (Aix Marseille University and Centre de la Recherche Scientifique, Aix-en-Provence, France), and works on music and religious heritage-making in southern Europe and the Mediterranean. He is the co-founder of the international network Respatrimoni and he recently edited with N. Cerezales The Religious Heritage Complex: Legacy, Conservation and Christianity (Bloomsbury). (isnartc@gmail.com) 